\title{
İletişimde Çözüm Odaklılık ÖIçeği’nin (İÇOÖ) Geliştirilmesi, Geçerlilik ve Güvenilirliği
}

\section{Dr. Ekrem Sedat Şahin ${ }^{1 *}$ Dr. Sümeyye Derin ${ }^{2}$}

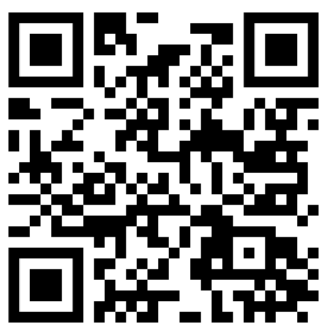

Geliş tarihi: 22.10 .2020

Kabul tarihi: 15.12 .2020

\section{Atıf bilgisi:}

IBAD Sosyal Bilimler Dergisi

Sayı: Özel Sayı Sayfa: 662-674

Yıl: 2020

This article was checked by Turnitin. Similarity Index 20\%

Bu makalede araştırma ve yayın etiğine uyulmuştur.

${ }^{1}$ Aksaray Üniversitesi, Türkiye,
ekremsedatsahin@aksaray.edu.tr, ORCID ID 0000-0002-2499-1617

2Sakarya Üniversitesi, Türkiye, sumeyyederin@sakarya.edu.tr ORCID ID 0000-0002-9102-7561

\footnotetext{
* Sorumlu yazar
}

ÖZ

Bu çalıșmada, yetişkin bireylerin iletișimde çözüm odaklılık düzeyini belirlemeye yönelik, geçerli ve güvenilir bir ölçme aracı geliştirmek amaçlanmıştır. Bu amaçla çözüm odaklı yaklaşımın, iletişim diğer bir ifade ile dilin kullanımı konusuna verdiği değer incelenmiştir. İletişim, çözüm odaklı yaklaşımın merkezindedir. Çözüme yönelmede ve ulaşmada dilin kullanımı belirleyici rol oynar. Çözüm odaklı dili kullanabilmek hem günlük hayatta hem de psikolojik danışmada probleme odaklanmak yerine çözüme odaklanmayı kolaylaştırabilir. Bu nedenlerle, çalışma kapsamında oluşturulan İletişimde Çözüm Odaklılık Ölçeği’nin (İÇOÖ) geliştirilmesi sürecinde; 18 yaş ve üzerinde, elverişli/ uygun örnekleme yoluyla ulaşılan, 237 erkek ve 226 kadın; toplam 463 yetişkin birey ile çalışılmıştır. Ölçeğin geçerlilik çalışması kapsamında kaynak tarama, uzman görüşü alma, pilot uygulama ve yap1 geçerliliğini inceleme gerçekleştirilmiştir. Yap1 geçerliliği kapsamında 223 bireyden elde edilen veriler SPSS 23.0 Programında Açımlayıcı Faktör Analizi (AFA) ile değerlendirilmiştir. AFA sonucunda ölçeğin 17 madde ve üç faktörden oluştuğu tespit edilmiştir. AFA'nın ardından ölçek yeniden farklı bir yetişkin grubuna uygulanmıştır. $\mathrm{Bu}$ uygulama sonucunda 182 yetişkinin verisiyle Doğrulayıcı Faktör Analizi (DFA) gerçekleştirilmiştir. DFA'da uyum indeksi değerleri ise $\mathrm{RMSEA}=.068 \mathrm{CFI}=.92, \mathrm{IFI}=.92, \mathrm{GFI}=.88, \mathrm{AGFI}=.83$ olarak bulunmuş ve DFA sonucunda ölçeğin 17 maddeli ve üç alt ölçekli yapıda, kabul edilebilir uyum değerlerine sahip olduğu tespit edilmiştir. İÇOÖ'nün güvenilirliği Cronbach Alfa (iç tutarlılık) yöntemi ile incelenmiştir. Ölçeğin hesaplanan Cronbach Alfa katsayısı .87'dir. Bu değer, ölçeğin yüksek düzeyde güvenilir bir ölçme aracı olduğunu göstermiştir. Sonuç olarak, yapılan analizler İÇOÖ’nün 18 yaş ve üzerindeki yetişkin bireylerin iletişimde çözüm odaklılıklarını belirlemek amacıyla kullanılabileceğini göstermiştir. Bulgular ilgili alanyazın ışı̆̆ında tartışılmıştır.

Anahtar Kelimeler: İletişimde Çözüm Odaklılık Ölçeği, geçerlilik, güvenilirlik 


\title{
Development, Validity and Reliability of the Solution Focality in Communication Scale (SFCS)
}

\author{
Dr. Ekrem Sedat Şahin ${ }^{1 *}$ \\ Dr. Sümeyye Derin ${ }^{2}$
}

First received: 22.10 .2020

Accepted: 15.12 .2020

\section{Citation:}

IBAD Journal of Social Sciences

Issue: Special Issue $\quad$ Pages: 662-674

Year: 2020

This article was checked by Turnitin. Similarity Index 20\%

1Aksaray University, Turkey,
ekremsedatsahin@aksaray.edu.tr,
ORCID ID 0000-0002-2499-1617

${ }^{2}$ Sakarya University, Turkey, sumeyyederin@sakarya.edu.tr ORCID ID 0000-0002-9102-7561

\footnotetext{
* Corresponding Author
}

\begin{abstract}
In this study, it is aimed to develop a valid and reliable measurement tool to determine the level of solution-focality in communication. For this purpose, the value given by the solution-focused approach to linguistic and communication has been examined. Linguistic, in other words, communication is at the center of the solution-focused approach. The use of linguistic plays a decisive role in orienting and reaching a solution. Using solution-focused linguistic can make it easier to focus on the solution instead of focusing on the problem in both daily life and psychological counseling. For these reasons, in the process of developing the Solution Focality in Communication Scale (SFCS), which was created within the scope of the study; 237 males and 226 females aged 18 years and over, available through convenience sampling; it was studied with a total of 463 adults. Within the scope of the validity study of the scale, source scanning, expert opinion, pilot application and construct validity were examined. Data obtained from 223 individuals within the scope of construct validity were evaluated by Explanatory Factor Analysis (EFA) in SPSS 23.0 Program. As a result of EFA, it was determined that the scale consists of 17 items and four factors. After EFA, the scale was applied to a different group of adults again. As a result of this application, Confirmatory Factor Analysis (CFA) was performed with the data of 182 adults. The fit index values in CFA were found as RMSEA $=.068 \mathrm{CFI}=.92$, IFI $=.92$, GFI $=.88, \mathrm{AGFI}=.83$, and as a result of CFA, the scale had acceptable fit values with 17 items and three subscales has been determined. The reliability of the SFCS was examined by the Cronbach Alpha (internal consistency) method. The calculated Cronbach Alpha coefficient of the scale is .87. This value showed that the scale is a highly reliable measurement tool. As a result, the analysis made showed that SFCS can be used to determine the solution-focused communication of adult individuals aged 18 and over. Findings were discussed in the light of the relevant literature.
\end{abstract}

Key Words: Solution Focality in Communication Scale, validity and reliability 


\section{GİRIŞ}

Birey, içinde bulunduğu zorlayıcı durumlara ilişkin psikolojik destek almaya ihtiyaç duyabilir. Psikolojik desteği sağlayan alan uzmanı, psikoterapide; bireyin yaşadığı probleme, danışma sürecine ve ekonomik koşullara bağlı olarak farklı psikolojik danışma yaklaşımlarını uygulayabilir. Günümüzde zamanın ve özellikle paranın tasarrufu açısından, daha çok kısa süreli psikoterapilere yönelim olduğu söylenebilir. Danışanın sorunlarının çözümüne hem kısa sürede yardım edilmesi ve hem de danışanın ekonomik açıdan daha az ödeme ile psikolojik destek alması için uygulanan yaklaşımlardan biri de çözüm odaklı terapi yaklaşımıdır.

Çözüm odaklı psikolojik danışma yaklaşımı yapısalcı ya da modernist değildir. Bu yaklaşımda psikolojik danışma, danışanın danışmaya getirdiği sorundan ve sorunun çeşidinden ziyade; çoklu bir bakış açısına dayanır. Belirtilen çoklu bakış açısına göre problemin altında yatan nedeni ya da problemin doğasını bilmek çözüm için gerekli değildir (Nelson, 2011). de Shazer (1991), bir sorunu çözmede, onun nedenini bilmenin gerekliliğine inandığını belirtir. Yazara göre sorun ve çözümü arasında bir ilişki vardır. Eğer sorunla çözümü arasında doğrudan bir ilişki olsaydı, her bireyin aynı soruna aynı çözümü uygulaması gerekebilirdi. Oysa her birey aynı soruna çok sayıda işe yarar çözüm üretebilir.

Çözüm odaklı psikolojik danışma yaklaşımında bireyin, problemlerinden daha fazlası olduğuna inanılır. Bireyde eksikliklerden çok kaynaklar aranır. Onun olası ve arzu ettiği hedefleri incelenir. Gelecekteki hayallerinin gerçekleşmesine o an bile katkıda bulunan durumlar araştırılır. Danışan kendi hayatının her alanında "uzman kişi” olarak görülür (Güner, 2014). Diğer bir deyişle çözüm odaklı psikolojik danışmada bireye sadece problemleri olan kişi olarak bakılmaz. Birey çözüme yönelik kaynakları olan, güçlü ve değişmek için ufak adımlar atmaya başlamış, kendi hayatının uzmanı olarak görülür.

Çözüm odaklı yaklaşımda, sorunun içindeki istisnai durum ve anlar ile danışanların işe yarar ne yaptığını bulmaya (Corey, 2008) ve bulunanları çözüm için uygun bir şekilde kullanmaya odaklanılır. Psikolojik danışma sürecinde üç temel kural takip edilir. Bu kurallardan birincisi; danışanın herhangi bir yakınması bulunmuyorsa burada bir müdahaleye gerek olmadığını ifade eden "bozulmamışsa onarma" kuralıdır. İkinci kural, sorunların çözümünde uygulanan yol ve yöntemler etkili ise bu yol ve yöntemleri daha çok kullanmak gerektiğini belirten "işleyen çözüm yollarına başvurmada ısrarlı olma"dır. Üçüncü ve son kural ise işlemediği kanıtlanan bir yöntemi yeniden uygulamanın herhangi bir yararı olmadığını anlatan "işlemeyen çözüm yollarına başvurmama, farklı çözüm yolları deneme"dir (Berg ve Miller, 1992). Özetle bireyde yolunda giden süreçlere zarar vermeden, uygulamalarda başarı sağlamayan çözümlerde ısrarcı olmadan işe yarayan yol, yöntem ve teknikleri uygulamak bu yaklaşımın temelindeki esaslardır.

Çözüm odaklı psikolojik danışma yaklaşımında danışanın sorundan ziyade çözüme ilişkin konuşması, içinde bulunulan an ya da gelecekte işleme ihtimali yüksek çözümlere odaklanması sağlanır (Doğan, 1999). Danışan ne yaşamış olursa olsun işe yarar olarak davranabilme yeteneğine sahiptir. Geleceğe ve çözümlere pozitif bakabilir, kendisinin tek bir yönden değil de farklı yönlerden ibaret olduğunu görebilir. Danışanların yaşadığı her sorunun mutlaka istisnası vardır. Danışanın yaşadığı ufak değişiklikler; büyük değişikliklere neden olur. Danışanlar, sorun çözmeye yönelik niyetlerine güvenebilmelidirler. Onlar, değişimi isterler, değişimin olması için ellerinden geleni yaparlar ve değişmeye yetecek kapasiteleri vardır (Walter ve Peller, 2000). Psikolojik danışmanlar bu varsayımlara dayanarak danışanlarla işbirliği gerçekleştirebilirler.

Çözüm odaklı psikolojik danışma yaklaşımında danışanın olumlu değişimine, kaynaklarına odaklanılır. Değişim, özellikle olumlu değişim kaçınılmazdır. Danışan kendi hayatının uzman kişisidir. Psikolojik danışma sürecinde danışman en uygun müdahale yöntemini seçer. Psikolojik danışman ile danışan arasında işbirliğine dayalı ve geleceğe odaklanılan bir ilişki oluşturulur. Bu ilişki faydacı ve esnektir. Psikolojik danışmada çözümler, danışan ve psikolojik danışmanın birlikte katılımıyla keşfedilir ve oluşturulur. Danışma sürecinde küçük değişimlerin daha büyük değişimlere yol açacağı ilkesi göz önüne alınır (Berg ve Miller, 1992; Davis ve Osborn, 2000). Çözüm odaklı psikolojik danışma sürecinde psikolojik danışmanın değil; danışanın isteklerine odaklanılır (Sklare, 2013). Özetle bu psikolojik danışma yaklaşımının özünde bireyin güçlü olduğuna, çözümleri görüp uygulayabileceğine ilişkin bir inanç bulunmaktadır. Psikolojik danışma süreci bu inanca uygun olarak planlanır ve uygulanır. 
Çözüm odaklı psikolojik danışma yaklaşımı, dilin önemini vurgular. Dili psikolojik danışmada etkili bir şekilde kullanan yaklaşıma göre dil, gerçekleri birlikte inşa etmenin bir aracıdır (Plosker ve Chang, 2014). Dil, terapötik sürecin merkezinde bulunan önemli bir öğedir. de Shazer'ın bu konudaki duruşu daha da radikaldir. Ona göre; "dil," insan dünyasını oluşturur ve insan dünyası da tüm dünyayı oluşturur (de Shazer ve Berg, 1992). Çözüm odaklı psikolojik danışma yaklaşımında kullanılan işbirlikçi dil ile terapötik değişim arasında pozitif ilişki olduğunu ispatlayan araştırmalar bunun tam tersini ortaya koyanlardan çok daha fazladır (Franklin, Zhang, Froerer ve Johnson, 2016). Özetle çözüm odaklı yaklaşımda dil önemli bir müdahale ve değişim aracıdır. Bu durumda çözüm odaklı yaklaşımda önemli bir değere sahip olan dilin bir ölçme aracı ile incelenmesi; hem psikolojik danışma sürecindeki terapötik ilerlemeyi tespit etmeyi hem de bireylerin günlük hayatlarında kurdukları iletişimde ne derecede çözüm odaklı olduklarını görmelerini sağlayabilir.

$\mathrm{Bu}$ açıdan bakıldığında, bireylerin iletişimde çözüm odaklılıklarının ölçülmesi hem uygulayıcılar için hem de ileride gerçekleştirilecek olan araştırmalar için önemli görünmektedir. Bu bağlamda, bu araştırmanın amacı yetişkin bireylere yönelik geçerliliği ve güvenilirliği sağlanmış, iletişimde çözüm odaklılık ölçeği geliştirerek uygulayıcıların ve araştırmacıların kullanımına sunmaktır.

\section{YÖNTEM}

İletişimde Çözüm Odakl1lık Ölçeği’nin (IÇOÖ) (Ek-1) geliştirilmesi ve psikometrik özelliklerinin incelenmesini amaçlayan bu araştırmada tarama yöntemi kullanılmıştır. Tarama yöntemi, geçmişte ya da içinde bulunulan anda var olan bir durumu mevcut şekliyle betimleme ve tanımlamayı amaçlayan araştırma yaklaşımıdır (Karasar, 2016). 18 yaş ve üstünde olan yetişkin bireylere yönelik olarak gerçekleştirilen bu araştırmada uygun/elverişli örnekleme yöntemi kullanılmıştır. Dörnyei’ye (2007) göre elverişli örnekleme, hedef kitlenin üyelerinin kolay erişilebilirlik, coğrafi yakınlık, belirli bir zamanda kullanılabilirlik veya istekli olma gibi belirli pratik kriterleri karşıladığı örnekleme yöntemidir. Bu yöntem ile 2019 yılının Ekim ve Kasım aylarında, çevrim içi süreçler aracılığıyla 463 yetişkin bireye veri toplama araçları uygulanmıştır.

\section{Çalışma Grubu}

Ölçek geliştirme sürecinde, öncelikle uygulama yapılacak örneklemin uygunluğu ve büyüklüğünün yeterliliği göz önüne alınır (Heppner, Wampold ve Kivlighan, 2008). Gorsuch (1990) ölçme aracındaki değişken/madde sayısının en az beş katı kadar, örneklemde birey olmasının uygun olacağını belirtir. Buna bağlı olarak çalışma kapsamında hazırlanan ölçme aracı çevrim içi anket şeklinde 18 yaş ve üstündeki 280 yetişkin bireye uygulanmıştır. Bu uygulamada ölçeğin 133 erkek ve 128 kadın olmak üzere 261 birey tarafindan eksiksiz doldurulduğu tespit edilmiştir. Ölçeği dolduran birey sayısı ölçme aracındaki değişken/madde sayısının 10 katından fazla olduğu bu bireylerin formlarından elde edilen bilgiler SPSS 23.0 programına aktarılarak İÇOÖ'nün Açımlayıcı Faktör Analizi (AFA) gerçekleştirilmiştir. AFA'nın ardından İÇOÖ Doğrulayıcı Faktör Analizi (DFA) için veri toplamak amacıyla; 215 bireye yukarıda ifade edilen iletişim kanalları ile gönderilmiştir. Bu gönderiye 98'i kadın ve 104'ü erkek olmak üzere toplam 202 yetişkin bireyin eksiksiz yanıt verdiği tespit edilmiştir. Özetle IÇOÖ'nün geliştirilme sürecinde çalışma grubunda 237 erkek ve 226 kadın; toplam 463 yetişkin birey ile çalışılmıştır.

\section{İletişimde Çözüm Odaklılık Ölçeği’nin (İÇOÖ) Geliştirilme Süreci}

Ölçeğin kimlere yönelik olduğu ve ölçek puanlarının hangi amaçla kullanılacağının tespit edilmesi (DeVellis, 2003) aşaması ölçme aracı geliştirmenin ilk basamağıdır. İÇOÖ'nün hedef kitlesi 18 yaş ve üzerindeki yetişkin bireylerdir. İÇOÖ'den elde edilen puanlar yetişkin bireylerin iletişimde çözüm odaklılıkları konusunda bilgi sağlayacaktır. DeVellis (2003) ölçek geliştirmede ikinci basamağın ölçülmek istenilen yapının kavramsallaştırılması olduğunu belirtmiştir. İÇOÖ, "iletişimde çözüm odaklılık" yapısını ölçmeye yönelik olarak hazırlanmıştır.

Ölçme aracı geliştirmenin üçüncü basamağında ölçülecek niteliğe en uygun maddelerin seçilmesi; alanyazına ve uzman görüşüne dayalı maddeler yazılarak madde havuzunun oluşturulması sağlanır (DeVellis, 2003). Bu kapsamda çözüm odaklı psikolojik danışma yaklaşımına yönelik olarak yurt dışı ve yurt içi alanyazını incelenerek madde havuzu oluşturulmuştur. Madde havuzundan seçilen maddeler 
psikolojik danışma ve rehberlik alanından en az doktora seviyesinde eğitim almış üç uzman tarafindan içerik açısından; alanında yüksek lisans yapmış üç Türkçe Öğretmeni tarafından dil açısından incelenmiştir. Alan ve dil uzmanlarının katkılarıyla ölçeğin 23 maddelik pilot uygulama formu hazırlanmıştır. Pilot uygulama formu 37 yetişkin bireye e-mail aracılığıyla gönderilerek uygulanmıştır. Uygulamaya katılan bireyler tarafından anlaşılmadığı ifade edilen maddeler düzeltilerek ölçme aracı deneme uygulamasına hazır hale getirilmiştir.

\section{BULGULAR VE YORUM}

Bu bölümde İÇOÖ’nün geçerliliği, güvenilirliği, puanlama ve yorumlanmasına ilişkin bilgiler sunulmuştur. İÇOÖ'nün yapı geçerliliği; AFA ve DFA ile iç tutarlılığı ise Cronbach Alfa güvenilirlik katsayısı hesaplanarak incelenmiştir.

\section{İletişimde Çözüm Odaklıık Ölçeği’nin (İÇOÖ) Geçerliliği}

İÇOÖ uygulamasından elde edilen verilerde ölçeğin her bir maddesinin normallik varsayımını sağlayıp sağlamadığını tespit etmek için çarpıklık (skewness) ve basıklık (kurtosis) katsayılarına bakılmıştır. Çarpıklık değerinin -1.81 ile -0.24 aralığında; basıklık değerinin ise -0.39 ile 1.57 aralığında değiştiği görülmüştür. Basıklık ve çarpıklık katsayılarının $+1,5$ ile $-1,5$ değerleri arasında olması kabul edilebilir düzeydir (Tabachnick ve Fidell, 2013). Ölçeğin verilerinin basıklık ve çarpıklık değerleri, kabul edilebilir seviyenin dışında olduğundan, verilerin malahobis uzaklıkları hesaplanarak uç değerlerin temizliği gerçekleştirilmiştir. Ardından çarpıklık ve basıklık değerleri yeniden hesaplanmıştır. Çarpıklık değerinin -1.04 ile -0.06 aralığında; basıklık değerinin ise -0.74 ile 1.45 aralığında değiştiği görülmüştür. Bu kapsamda ölçeğin verilerinin normal dağılıma sahip olduğuna karar verilerek AFA'ya geçilmiştir. Uç değerler çıkarıldıktan sonra 223 bireyin verisi ile AFA gerçekleştirilmiştir.

Herhangi bir veri grubuna AFA uygulanabilmesi için verilerin faktör analizine uygun olması ve örneklemdeki birey sayısının yeterli olması gerekir. AFA için Bartlett Küresellik Testi (Bartlett Test of Sphericity) ve Kaiser-Meyer-Olkin (KMO) Testi (Karaman, 2015) sonuçlarına bakılır. Bartlett Küresellik Testi, ölçme aracının verisinin çoklu normal dağılımdan gelmiş olmasını gerektirir. Belirtilen test sonucunda değer, düşük olursa sıfır hipotezi; yüksek olursa alternatif hipotez kabul edilir. Sifır hipotezi red edilmediğinde faktör analizine devam edilemez (Akgül ve Çevik, 2003; Karagöz, 2016). Ölçeğin verilerinin faktör analizine uygunluğunu incelerken yapılması gereken diğer bir test KaiserMeyer-Olkin (KMO) Testidir. KMO Testi, örneklemin yeterliliği hakkında bilgi verir (Karaman, 2015). KMO değeri, .50'den küçük olduğunda kabul edilemez, .50-.60 arası ise kötü, .60-.70 arasındaysa zayıf/ vasat, .70-.80 arası olduğunda orta, .80-.90 arasında ise iyi, .90'1n üzerinde ise mükemmeldir (Kaiser, 1974). İÇOÖ uygulamasından elde edilen 223 veriye Kaiser-Meyer-Olkin (KMO) Testi ile Bartlett Küresellik Testi ugulandığında aşağıdaki sonuçlar elde edilmiştir.

Tablo 1. IÇOÖ Kaiser-Meyer-Olkin (KMO) ve Bartlett Küresellik Testi Sonuçları

\begin{tabular}{lcc}
\hline KMO ve Bartlett Testi & \\
\hline Kaiser-Meyer-Olkin Testi & Örneklem Yeterliliğinin Ölçümü & .88 \\
Bartlett'in Küresellik Testi & Yaklaşık Ki-Kare & 1296.91 \\
& $\mathrm{sd}$ & 136 \\
& $\mathrm{p}$ & .000 \\
\hline
\end{tabular}

Faktör analizi gerçekleştirmek için değişkenler/maddeler arasındaki ilişkinin yüsekliğine bakı1ır. Tablo 1'de görüldüğü üzere $\mathrm{p}<.05$ olduğundan Bartlett Küresellik Testi'nin sonucu anlamlıdır. Bu durum, değişkenler arasında yüksek korelasyonun olduğunu ve verilerin çoklu dağılımdan geldiğini gösterir. KMO değeri .88 olduğundan sonuç "iyi” olarak değerlendirilmiş ve örneklem büyüklüğünün yeterli (Karaman, 2015) olduğuna karar verilerek, faktör analizi gerçekleştirilmiştir.

Kuramsal olarak faktör analizinin başında, ölçekteki madde-değişken sayısı kadar faktör bulunur (Büyüköztürk, 2010). Burada amaç, maddeler arasındaki ilişkileri en üst seviyede temsil eden az sayıda faktörü belirlemektir. İşlem sonucunda ortaya kaç tane faktör çıkacağı ile ilgili değişik kıstaslar mevcuttur (Karagöz, 2016; Özdamar, 2002; Tavşanc11, 2002). Bu kıstaslardan birincisi öz-değeri 1 olan 
ve 1'den yüksek olan faktörlerin değerlendirmeye alınmasıdır (Özdamar, 2002). İkinci kıstas ise maddelerin faktörlere yerleşiminin incelenmesidir.

İÇOÖ maddelerinin faktörlere dağılımını belirleyerek, yorumlanıp; isimlendirilebilecek faktörler oluşturmak için Orthogonal rotasyon yöntemleri içinde yeralan "Varimaks" tekniği uygulanmıştır. Varimaks tekniğinde basit yapıya ve anlamlı faktörlere erişmede faktör yükleri matrisinin sütunları öncelikle ele alınır (Karagöz, 2016). Analizde hedef varyansı en yüksek düzeyde çıkarmaktır. Varimaks, varyansı en yüksek seviyede ortaya çıkaran döndürme tekniğidir (Karaman, 2015).

Tabachnick ve Fidell (2013) faktör belirlemede döndürme işleminin uygulanıp; yorumlanmasının gerekli olduğunu ifade eder. Faktör sayısına karar verilirken her bir yöntemde döndürülmüş faktör matrisine bakılır. Faktör sayısı belirlenirken bir maddenin faktör yükünün minimum .30 olmasına ve ayrıca aynı madde birden fazla faktörde yük verdiğinde iki faktör arasındaki bu değerin farkının minimum .1 olmasına dikkat edilir (Stevens, 2002). Maddenin faktör yük değerinin minimum .32 olması (Tabachnick ve Fidell, 2013) gerektiğini belirten yazarlar da vardır. Bazı durumlarda faktör yükünün negatif olduğu da görülebilir. Bunun anlamı; bu faktörün o değişkenle ters ilişkili olduğudur (Kline, 1994). Ayrıca kararlı bir faktörün en az üç değişken/madde içermesi gerekir (MacCallum, Widaman, Zhang ve Hong 1999). İÇOÖ, açımlayıcı faktör analizinde maddelerin faktör yük değeri .40 olarak belirlenmiş ve yukarıda belirtilen kurallara uygun olarak analizler gerçekleştirilmiştir.

İlk faktör analizinde elde edilen "döndürülmüş bileşen matriksleri” incelendiğinde ölçeğin altı faktörlü bir yapıda olduğu ve 6 . faktörde sadece bir madde bulunduğu görülmüştür. Kararlı bir faktörde en az üç madde bulunması gerektiği kuralına bağlı olarak 6. faktördeki madde 18 çıkarılarak yeniden AFA gerçekleştirilmiştir. İkinci AFA'nın “döndürülmüş bileşen matriksleri” incelendiğinde ölçeğin beş faktörlü olduğu ancak 5. faktörde madde 4'ün tek olduğu tespit edilmiştir. Bu nedenle madde 4 çıkarılarak yeniden bir analiz yapılmıştır. Üçüncü AFA'nın "döndürülmüş bileşen matriksleri”" incelendiğinde ölçeğin dört faktörlü olduğu ancak 4. faktörde 1. ve 14. maddenin olduğu görülmüştür. Ayrıca madde 19 ve 21 'in ikinci ve üçüncü faktörde olmasına rağmen madde faktör yükleri arasında .1 'den daha az fark olduğu tespit edilmiştir. Bu nedenle madde 1 ve 14 ile 19 ve 21 çıkarılarak yeniden bir analiz yapılmıştır. Dördüncü analiz sonucunda ölçeğin 17 maddeden ve üç alt ölçekten meydana geldiği belirlenmiştir. Bu analize ilişkin “açıklanan toplam varyans” Tablo 2'de sunulmuştur.

Tablo 2. IÇOÖ Açıklanan Toplam Varyans Değerleri

\begin{tabular}{|c|c|c|c|c|c|c|c|c|c|}
\hline \multirow[b]{2}{*}{ Bileşen } & \multirow[b]{2}{*}{ Özdeğer } & \multicolumn{3}{|c|}{ İlk Özdeğerler } & \multicolumn{3}{|c|}{ Cikarılan Boyutlar } & \multicolumn{2}{|c|}{ Döndürme İșleminden Sonra } \\
\hline & & $\begin{array}{c}\text { Açılklanan } \\
\text { varyans } \\
\text { Yüzdesi }\end{array}$ & $\begin{array}{r}\text { Toplam } \\
\text { Açıklanan } \\
\text { Varyans } \\
\text { Değeri }\end{array}$ & Özdeğer & $\begin{array}{r}\text { Açıklanan } \\
\text { varyans } \\
\text { Yüzdesi }\end{array}$ & $\begin{array}{r}\text { Toplam } \\
\text { Açıklanan } \\
\text { Varyans } \\
\text { Değeri }\end{array}$ & Özdeğer & $\begin{array}{r}\text { Açıklanan } \\
\text { varyans } \\
\text { Yüzdesi }\end{array}$ & $\begin{array}{c}\text { Toplam } \\
\text { Açılanan } \\
\text { Varyans } \\
\text { Değeri }\end{array}$ \\
\hline 1 & 5,925 & 34,852 & 34,852 & 5,925 & 34,852 & 34,852 & 3,675 & 21,620 & 21,620 \\
\hline 2 & 1,722 & 10,127 & 44,980 & 1,722 & 10,127 & 44,980 & 3,117 & 18,336 & 39,956 \\
\hline 3 & 1,201 & 7,063 & 52,042 & 1,201 & 7,063 & 52,042 & 2,055 & 12,086 & 52,042 \\
\hline 4 & ,992 & 5,833 & 57,875 & & & & & & \\
\hline 5 & 881 & 5,182 & 63,057 & & & & & & \\
\hline 6 & ,793 & 4,664 & 67,722 & & & & & & \\
\hline 7 & ,773 & 4,546 & 72,268 & & & & & & \\
\hline 8 & 689 & 4,052 & 76,320 & & & & & & \\
\hline 9 & 642 & 3,776 & 80,097 & & & & & & \\
\hline 10 &, 578 & 3,398 & 83,494 & & & & & & \\
\hline 11 &, 528 & 3,106 & 86,601 & & & & & & \\
\hline 12 & ,465 & 2,738 & 89,338 & & & & & & \\
\hline 13 & ,429 & 2,525 & 91,863 & & & & & & \\
\hline 14 & ,412 & 2,422 & 94,285 & & & & & & \\
\hline 15 & ,366 & 2,154 & 96,439 & & & & & & \\
\hline 16 & ,318 & 1,871 & 98,310 & & & & & & \\
\hline 17 & ,287 & 1,690 & 100,000 & & & & & & \\
\hline
\end{tabular}


Tablo 2'de görüldüğ̈̈ gibi ilk özdeğerleri 1'in üstünde olan üç faktör bulunmakta ve bu faktörler toplam varyansın yüzde 52.04'ini açıklamaktadır. Son analizin “döndürülmüş bileșen matriksleri” de Tablo 3 'te sunulmuştur.

Tablo 3. IÇOÖ Döndürülmüş Bileşen Matriksleri

\begin{tabular}{|c|c|c|c|}
\hline & \multicolumn{2}{|c|}{ Bileşenler } & \multirow[b]{2}{*}{3} \\
\hline & 1 & 2 & \\
\hline M23 &, 759 & & \\
\hline M17 &, 740 & & \\
\hline M20 & ,668 & & \\
\hline M10 & ,612 & & \\
\hline M13 & 610 & & \\
\hline M5 & ,597 & & \\
\hline M22 & ,490 & & \\
\hline M11 & ,485 & & \\
\hline M9 & & ,716 & \\
\hline M7 & &, 716 & \\
\hline M6 & & 662 & \\
\hline M8 & & 653 & \\
\hline M12 & & 612 & \\
\hline M2 & & & ,785 \\
\hline M3 & & &, 712 \\
\hline M16 & & &, 582 \\
\hline M15 & & & ,499 \\
\hline
\end{tabular}

Tablo 3 incelendiğinde, İÇOÖ’nün “döndürülmüş bileşen matrikslerine” göre üç alt ölçeğinin bulunduğu görülür. Birinci alt ölçek sekiz, ikincisi beş ve üçüncü alt ölçek ise dört maddeden oluşmaktadır.

İÇOÖ’nün yamaç eğim grafiğinde (Scree Plot) maddelerin faktörlere dağılımı daha net bir şekilde görülebilir. Yamaç eğim grafiği Şekil 1'de sunulmuştur.

Şekil 1. IÇOÖ Yamaç Ĕ̈im (Scree Plot) Grafiği

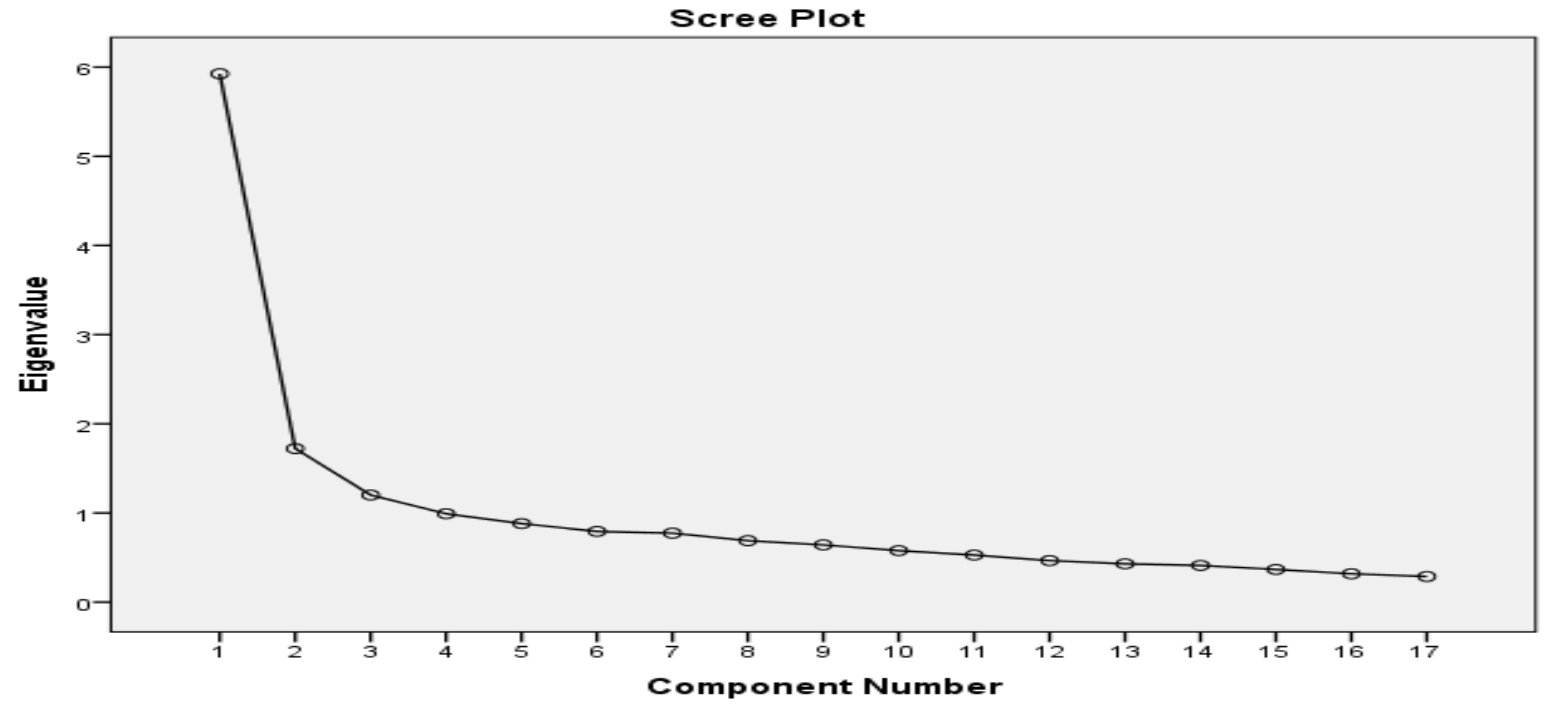

Özdeğerler, yamaç eğim grafiği ile incelenir. Burada düşey çizginin yataylaştığı noktaya kadar olan faktörler yoruma dahil edilir (Karagöz, 2016). İÇOÖ yamaç eğim grafiği incelendiğinde üç faktörden sonra çizginin yataylaştığı görülür.

AFA sonucunda İÇOÖ; "açıklanan toplam varyans değeri”, "döndürülmüş bileşen matriksleri” ve yamaç eğim grafiği incelendiğinde maddelerin üç faktörde toplandığı görülmüştür. Ölçeğin AFA sonuçlarını 
değerlendirmek amacıyla DFA yapılmasına karar verilerek, 17 maddelik form 215 yetişkin bireye gönderilmiş ve bu gönderiye cevap veren 202 bireyin verisi ile doğrulayıcı faktör analizi gerçekleştirilmiştir.

Bilimsel araştırma metodunu uygulamadan önce ölçeğin her bir maddesinin normallik varsayımını sağlayıp sağlamadığını kontrol etmek için çarpıklık (skewness) ve basıklık (kurtosis) katsayıları incelenmiştir. Verilerinin basıklık ve çarpıklık değerleri tespit edilmeden malahobis uzaklıkları hesaplanarak uç değerlerin temizliği gerçekleştirilmiştir. Çarpıklık değerinin -0.59 ile 0.98 aralığında; basıklık değerinin ise -1.06 ile 0.52 aralığında değiştiği görülmüştür. Basıklık ve çarpıklık değerlerinin $+1,5$ ve $-1,5$ değerleri arasında olması kabul edilebilir düzeyde (Tabachnick ve Fidell, 2013) olduğu için 17 maddelik formun verilerinin normal dağılıma sahip olduğuna karar verilerek DFA'ya geçilmiştir. Uç değerler çıkarıldıktan sonra 182 bireyin verisi ile DFA gerçekleştirilmiştir.

Doğrulayıcı faktör analizi, önceden oluşturulan bir model araca1lı̆̆ıyla gözlenen değişkenlerden hareket edilerek gizil değişken (faktör) oluşturmaya dönük bir işlemdir (Myers, 2000). Bu işlemde araştırmacılar ölçüm hataları arasındaki ilişkiyi tespit ederken; faktörlerin birbirleri ile korelasyonlarının eşit olmasını bekler (Aytaç ve Öngen, 2010; Günden ve Miran, 2008). İşleme alınan model, araştırmacı tarafindan tamamen kuramsal olarak belirlenip DFA ile test edilmiş ya da AFA sonucunda elde edilmiş olabilir (Schmitt, 2011). Önceki bölümlerde de ifade edildiği gibi İÇOÖ’nün AFA'sı sonucunda ortaya çıkan üç faktörlü yapısının uygunluğunun tespit edilmesi amcıyla "SPSS AMOS 23" kullanılarak doğrulayıcı faktör analizi gerçekleştirilmiştir.

DFA'da model uyumunun test edilmesi amaciyla farklı istatistikler bulunur. Bu istatistiklerin arasında en çok kullanılanların Ki-kare istatistiği, RMSEA GFI ve CFI olduğu söylenebilir (Aytaç ve Öngen, 2010; Karagöz, 2016). Ki-kare istatistiği (Chi-Square Goodness), $\chi 2 / \mathrm{df}<2$ ise mükemmel uyumu ve $\chi 2 / \mathrm{df}<3$ ise kabul edilebilir bir uyumu ifade eder (Kelloway, 1998). Bryne (2001) Ki-kare istatistiği (Chi-Square Goodness) $\chi 2 / \mathrm{df}<5$; karşılaştırmalı uyum indeksi (Comparative Fit Index) CFI $>$.90; yaklaşık hataların ortalama karekökü'nün (Root Mean Square Error of Approximation) RMSEA $<.070$ olması gerektiğini vurgular. Diğer değerler, iyilik uyum indeksi (Goodness of Fit Index) GFI $\geq .85$ ve düzeltilmiş uyum iyiliği indeksi (Adjusted Goodness of Fit Index) AGFI $\geq .85$ olduğunda modelin uygunluğunun kabul edilebilir (Jöreskog ve Sörbom, 1993; Karagöz, 2016; Marsh, Balla ve McDonald, 1988) olduğu ifade edilmiştir.

İÇOÖ’nün AFA sonucunda ortaya çıkan 17 maddeli ve üç faktörlü yapısına DFA uygulanarak ortaya çıkarılan kovaryans matrisleri incelenmiştir. Burada ilk modelin uyum indeksleri; $\chi 2(\mathrm{df}=116, \mathrm{n}=182)=$ $269.479, \mathrm{p}<.00 ; \chi 2 / \mathrm{df}=2.32 ; \mathrm{GFI}=.86 ; \mathrm{CFI}=.88 ; \mathrm{AGFI}=.80 ; \mathrm{IFI}=.88$ ve RMSEA $=.085$ şeklinde ortaya çıkmıştır. Yukarıda sunulan bilgiler 1şığında ölçeğin 17 maddelik formunun bazı uyum indeks değerlerinin kabul edilebilir düzeyde olduğu; ancak bazılarının kabul edilebilir düzeyde olmadığı söylenebilir. Karagöz'e (2016) göre DFA'da modifikasyon indeksleri incelenerek uygun düzeltmeler gerçekleştirilebilir. Modifikasyon indekslerinin gösterdiği düzeltmeler gerçekleştirildiğinde model daha iyi bir uyum ortaya koyar. Düzeltmeler, kuramsal yapı ile uyumlu olmalıdır. İÇOÖ’nün modifikasyon indeksleri incelenerek birinci faktörde iki madde arasında karşıllıkı bir şekilde hata kovaryansları ilişkilendirilmiş ve düzenlenmiş modelin uyumluluk indeksleri tekrar test edilmiştir. Test sonuçları Tablo 4 'te sunulmuştur.

Tablo 4. IÇOÖ Doğrulayıcı Faktör Analizi Sonuçları

\begin{tabular}{llllllll}
\hline$\chi^{2}$ & $\mathrm{p}$ & $\chi 2 / \mathrm{sd}$ & GFI & AGFI & CFI & IFI & RMSEA \\
\hline 209.426 & .00 & 1.84 & .88 & .83 & .92 & .92 & .068 \\
\hline
\end{tabular}

Tablo 4'te sunulan değerler incelendiğinde İÇOÖ'nün 17 maddeli ve üç faktörlü bir modelde kabul edilebilir uyum düzeyine sahip olduğu görülür. İÇOÖ'nün alt ölçeklerindeki madde içerikleri göz önüne alınarak ilk faktörü "Illetişime Çözüm Odaklı Müdahale"; ikinci faktörü "İletişimde Çözüm Fırsatlarını Değerlendirme" ve üçüncü faktörü ise "İletişime Çözüm Odaklı Yaklaşım" şeklinde isimlendirilmiştir. DFA sonucunda elde edilen yapı, Şekil 2'de sunulmuştur. 
Şekil 2. IÇOÖ’ye Illişkin Doğrulayıcı Faktör Analizi Modeli

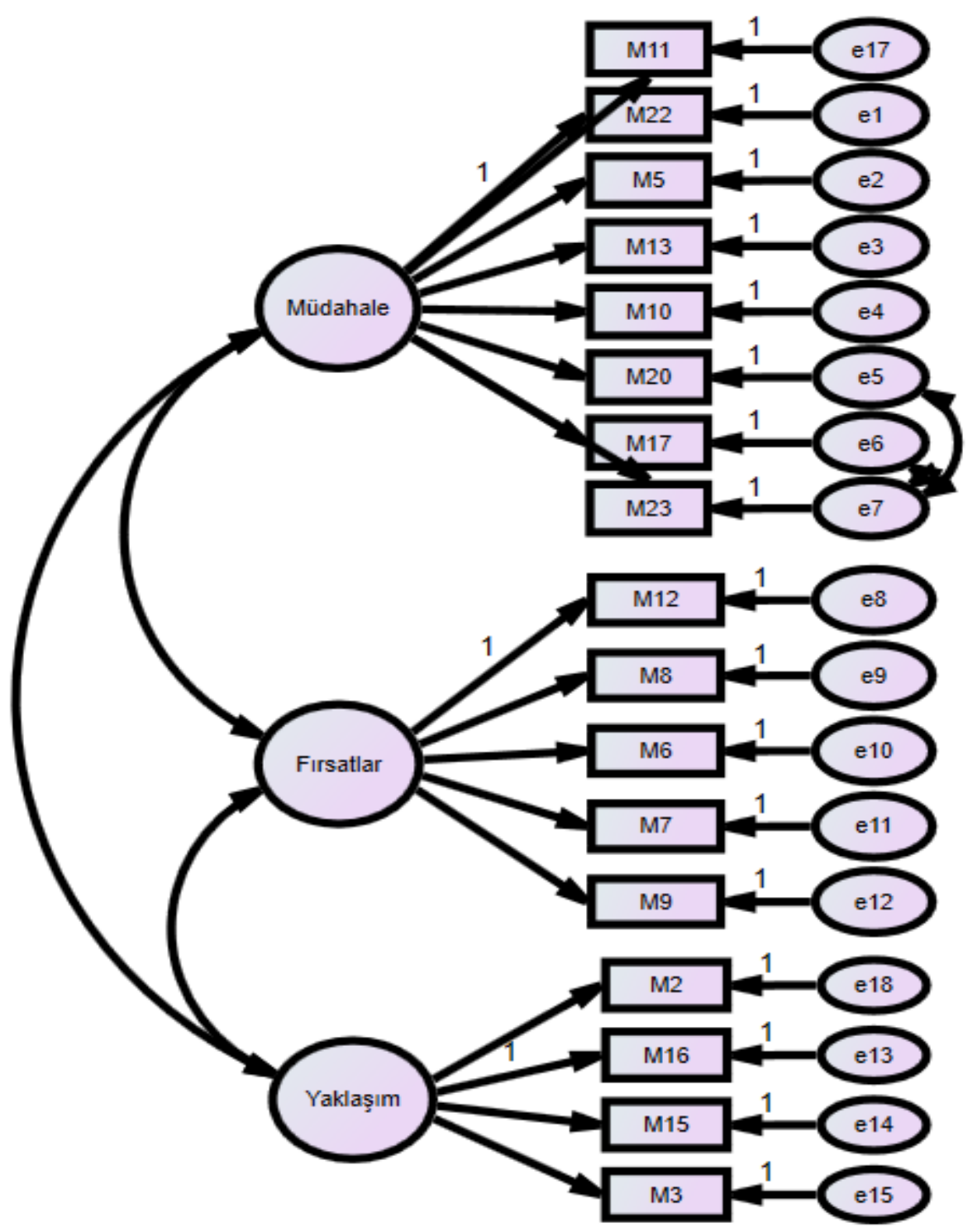

\section{İletişimde Çözüm Odaklılık Ölçeği’nin (İÇOÖ) Güvenilirliği}

İÇOÖ’nün güvenilirliği iç tutarlılık yöntemi ile incelenmiştir. İç tutarlılık yöntemi için Cronbach Alfa Katsayısı hesaplanmıştır. İÇOÖ’nün Cronbach Alfa Katsayısı .87 olarak bulunmuştur. Karagöz'e (2016) göre ölçme aracının Cronbach Alfa katsayısı .80'in üzerinde ise araç, iç tutarlılı̆̆ 1 olan, yüksek derecede güvenilir bir ölçme aracıdır. Buna istinaden İÇOÖ’nün yüksek derecede güvenilir bir ölçme aracı olduğu söylenebilir.

\section{İletişimde Çözüm Odaklılık Öıçeği’nin (İÇOÖ) Puanlanması ve Yorumlanması}

İÇOÖ’nün puanlamasında her bir madde için 1-5 arasında değişen yanıt seçeneği dikkate alınır. İÇOÖ maddelerine verilen cevabın olumluluğu 1'den 5'e doğru gidildikçe artar. İÇOÖ'nün 10. maddesi ters puanlanır. Ölçekten minimum 17 ve maksimum 85 puan alınmaktadır. Ölçekten alınan puan yükseldikçe bireyin iletişimde çözüm odaklılık düzeyinin yüksek olduğu söylenebilir.

\section{TARTIŞMA, SONUÇ VE ÖNERILER}

Çözüm odaklı psikolojik danışma yaklaşımı bireyin kaynaklarını ve kendini toparlama gücünü; amaçlı, olumlu değişim için bu kaynak ve gücün nasıl kullanılacağını ifade eden bir yaklaşımdır. Çözüm odaklı psikolojik danışma yaklaşımına alanyazında gün geçtikçe artan bir ilgi olmakla birlikte, bu yaklaşımın uyguladığı süreç ve mekanizma hakkında az sayıda araştırma bulunmakadır (Grant, Cavanagh, 
Kleitman, Spence, Lakota ve Yu, 2012). İletişimde Çözüm Odaklılık Ölçeği (İÇOÖ) bu yaklaşımın iletişime verdiği öneme dayanarak geliştirilmiştir. İÇOÖ'nün geçerlilik ve güvenilirlik çalışmalarına ilişkin ortaya çıkan bulgular ölçeğin, yetişkin bireylerin iletişimde çözüm odaklılık düzeylerini belirlemeye yönelik olarak kullanılabileceğini göstermektedir. İÇOÖ’nün geçerlilik çalışmaları kapsamında uygulanan AFA ve DFA, ölçeğin üç faktörlü yapıdan oluştuğunu göstermiştir. DFA sonucunda elde edilen RMSEA değeri .068 olarak tespit edilmiştir. Bu değer üç faktörlü yapının kabul edilebilir uyum gösterdiğini ifade etmektedir. İÇOÖ'nün Cronbach Alfa katsayıs1 .87 bulunmuştur. $\mathrm{Bu}$ değer, ölçeğin güvenilirlik düzeyinin yüksek olduğunu ifade etmektedir.

Çözüm odaklı psikolojik danışma yaklaşımında dilin kullanımı diğer bir ifade ile iletişim tarzı, psikolojik danışma sürecinin önemli bir öğesidir (Sánchez-Prada ve Beyebach, 2014). Bireyin çözüme odaklanıp ulaşması ve değişimi sağlamasında kullanılan dil ve ona bağlı oluşan iletişim değerlidir. Bu durumda bireylere, "iletişimde çözüm odaklılık" öğretilerek onların günlük hayat içinde çözümlere ulaşması sağlanabilir. Bu kapsamda çözüm odaklı yaklaşımın temel kavramları bireylere kavratılır; onların kendi kendilerine uyum güçlüklerinin üstesinden gelmesi sağlanabilir.

Çözüm odaklı psikolojik danışma yaklaşımının temelde oldukça rahat ve kolay uygulanabilir görünmektedir. Birey problemini çözme veya zorlukların üstesinden gelebilme konusunda yeterli kaynaklara sahiptir. Çözüm odaklı psikolojik danışma oturumu beklendik çözüme ulaşmayı sağlayan bir araçtır (Jackson ve McKergow, 2002). Alanyazın incelendiğinde çözüm odaklı yaklaşıma dayalı; sınav kaygısıyla başa çıkma eğitim programı (İşlek, 2006), sınav kaygısı, saldırganlık eğilimi ve problem çözme becerileri (Sarıc1-Bulut, 2008) öfke kontrolü (Siyez ve Tuna, 2014) eğitim programlarının hazırlandığı ve uygulandığı görülür. Bu programlara benzer şekilde bireysel uyum güçlüklerinin bireyin kendisi tarafından ortadan kaldırmasında çözüm odaklı yaklaşımın dil ve iletişim konusundaki içeriği ön plana çıkarılarak eğitim programları hazırlanıp uygulanabilir. Bireyin hayatının geri kalanında bu stratejileri kullanması sağlanabilir.

İletişimde Çözüm Odaklılık Ölçeği (İÇOÖ), Türk kültürüne özgü olarak geliştirilmiştir. İÇOÖ başta psikolojik danışmanlar, psikiyatristler, psikologlar ile sosyal hizmet uzmanları gibi insana yardım mesleği üyeleri ve bu konuda araştırma yapmayı planlayan profesyoneller tarafindan kullanılabilir. İÇÖ, iletişimde çözüm odaklılık konusunda gerçekleştirilecek araştırmalarda kullanılabilir. Yine bu konuda deneysel çalışmalar gerçekleştirmeyi planlayan alan uzmanlarına, ölçme aracı olarak katkı sağlayabilir. Özetle İÇOÖ, çözüm odaklı psikolojik danışma yaklaşımı konusunda psikolojik danışmanlar ve diğer insana yardım mesleği uzmanları için bir başvuru kaynağı olabilir.

\title{
Bilgilendirme / Acknowledgement:
}

\author{
Yazarlar aşağılaki billgillendirmeleri yapmaktadırlar: \\ 1- Araştırmacıların katkı oranı eşittir. \\ 2- Bu çalışma, 04 Aralık 2020 - 05 Aralık 2020 tarihleri arasında düzenlenen Uluslararasi Marmara Sosyal Bilimler \\ Kongresi'nde sözlü bildiri olarak sunulmuştur. \\ 3- Makalenin yazarları arasında çıkar çatışması bulunmamaktadır. \\ 4- Çalışmanın verileri 2019 yılında toplanmış ve yorumlanmıştır. \\ 5- Bu makalede araştırma ve yayın etiğine uyulmuştur.
}




\section{KAYNAKÇA}

Akgül, A., \& Çevik, O. (2003). Istatistiksel analiz teknikleri. Ankara: Emek Ofset.

Aytaç, M., \& Öngen, B. (2010). Doğrulayıcı faktör analizi ile yeni çevresel paradigma ölçeğinin yap1 geçerliliğinin incelenmesi. İstatistikçiler Dergisi, 5, 14-22.

Berg I. K. \& Miller S. D. (1992). Working with problem drinker: A solution-focused approach. New York: W. W. Norton \& Company Inc.

Bryne, B. M. (2001). Structural equation modeling with AMOS. Mahwah, NJ: Lawrence Erlbaum Associates.

Büyüköztürk, Ş. (2010). Sosyal bilimler için veri analizi el kitabl. Ankara: Pegem Akademi Yayıncilik.

Corey, G. (2008). Psikolojik danışma kuram ve uygulamaları. (Çev. T. Ergene). Ankara: Mentis Yayıncilik.

Davis, T. E. \& Osborn, C. T. (2000). The solution focused school counselor: Shaping Professional Practice. New York: Taylor \& Francis.

de Shazer, S. (1991). Putting difference to work. New York: Norton.

de Shazer, S., \& Berg, I. K. (1992). Doing therapy: A post-structural re-vision. Journal of Marital and Family Therapy, 18, 71- 81.

de Jong, P. \& Berg, I. K. (1998). Interviewing for solutions. Pacific Grove CA: Brooks/ Cole.

DeVellis, R. F. (2003). Scale development: Theory and applications. London: Sage.

Doğan, S. (1999). Çözüm odaklı kısa süreli danışma: Kuramsal bir inceleme. Türk Psikolojik Danışma \& Rehberlik Dergisi, 2(12) 28- 38.

Dörnyei, Z. (2007). Research methods in applied linguistics. New York: Oxford University Press.

Franklin, C., Zhang, A. Froerer, A. \& Jonhnson, S. (2016). Solution focused brief therapy: A systematic review and meta summary of process research. Journal of Marital and Family Therapy 43(1), 16- 30.

George, D., \& Mallery, M. (2010). SPSS for windows step by step: A simple guide and reference. Boston: Allyn \& Bacon.

Gorsuch, R. L. (1990). Common factor-analysis versus component analysis- Some well and little known facts. Multivariate Behavioral Research, 25(1), 33-39.

Grant, A. M. , Cavanagh, M. J. , Kleitman, S. , Spence, G. , Lakota, M. , Yu, N. (2012). Development and validation of the solution-focused inventory. The Journal of Positive Psychology, 7(4), 334-348.

Günden, C., \& Miran, B. (2008). Yeni çevresel paradigma ölçeğiyle çiftçilerin çevre tutumunun belirlenmesi: İzmir ili Torbalı ilçesi örneği. Ekoloji Dergisi, 18(69), 41-50.

Güner, O. (2014). Çözüm bende sakll! Çözüm odaklı danışma yöntemi. Ankara: Efil Yayınevi.

Heppner, P. P., Wampold, B. E., \& Jr. Kivlighan, D. M. (2008). Psikolojik danışmada araştırma yöntemleri. (D. M. Siyez. Çev. Ed.) Ankara: Mentis Yayıncılık.

İşlek, M. (2006). Çözüm odaklı yaklaşımlara göre düzenlenmiş sınav kaygısıyla başa çıkma eğitim programının üniversiteye hazırlanan ögrencilerin sınav kaygısı düzeylerine etkisi. Yayınlanmamış yüksek lisans tezi, Hacettepe Üniversitesi, Ankara.

Jackson, P.Z., \& McKergow, M. (2002). The solutions focus: The SIMPLE way to positive change. London: Nicholas Brealey. 
Jöreskog, K. G., \& Sörbom, D. (1993). LISREL 8: Structural equation modeling with the SIMPLIS command language. USA: Scientific Software International; Lawrence Erlbaum Associates, Inc.

Kaiser, H. F. (1974). An index of factorial simplicity. Psychometrika, 39, 31-36.

Karagöz, Y. (2016). SPSS 23 ve AMOS 23 uygulamalı istatistiksel analizler. Ankara: Nobel Akademik Yayıncilik.

Karaman, H. (2015). Açımlayıcı faktör analizinde kullanılan faktör çıkartma yöntemlerinin karşılaştırılması. Yayımlanmamış yüksek lisans tezi, Hacettepe Üniversitesi, Ankara.

Karasar, N. (2016). Bilimsel araştırma yöntemi. Ankara: Nobel Akademik Yayıncılık.

Kelloway, E. K. (1998). Using LISREL for structural equation modeling. Thousand Oaks, CA: Sage Publishers.

Kline, P. (1994). An easy guide to factor analysis. London: Routledge.

MacCallum, R. C., Widaman, K. F., Zhang, S., \& Hong, S. (1999). Sample size in factor analysis. Psychological Methods, 4(1), 84-99.

Marsh, H. W., Balla, J. R., \& McDonald, R. P. (1988). Goodness-of-fit indexes in confirmatory factor analysis: The effect of sample size. Psychological Bulletin, 103(3), 391-410.

Myers, W. H. (2000). A structural equation model of family factors associated with adolescent depression. Dissertation Abstracts International: Section B: The Sciences and Engineering, $61,1620$.

Nelson, T. S. (2011). Solution-focused brief couple therapy. In D. K. Carson, \& M. Casado-Kehoe (Eds.). Case studies in couples therapy: theory-based approaches. 275-287. USA: Taylor and Fracis Group, LLC.

Özdamar, K. (2002). Paket programlar ile istatistiksel veri analizi. Eskişehir: Kaan Kitabevi.

Plosker, R. \& Chang, J. (2014). A solution-focused therapy group designed for caregivers of stroke survivors. Journal of Systemic Therapies, 33(2), 35-49.

Sánchez-Prada, A. \& Beyebach, M. (2014). Solution-focused responses to "No improvement ": A qualitative analysis of the deconstruction process. Journal of Systemic Therapies, 33(1), 4861.

Sarıc1- Bulut, S. (2008). Illkögretim ikinci kademe ögrencilerinin sinav kaygllarl, saldırganlık eğilimleri ve problem çözme becerilerindeki yetersizliklerin sağaltımlarında grupla çözüm odaklı kısa terapinin etkileri. Yayınlanmamış doktora tezi, Atatürk Üniversitesi, Erzurum.

Schmitt, T. A. (2011). Current methodological considerations in exploratory and confirmatory factor analysis. Journal of Psychoeducational Assessment, 29(4) 304-321.

Siyez, D. M. \& Tuna, D. T. (2014). Çözüm odaklı kısa süreli yaklaşıma dayalı öfke kontrolü eğitim programının lise öğrencilerinin öfke kontrolü ve iletişim becerileri düzeylerine etkisi. Türk Psikolojik Danısma ve Rehberlik Dergisi, 5(41), 11-22.

Sklare, G. B. (2013). Okul danışmanları için çözüm odaklı kısa süreli psikolojik danışma. (Çev. D. M. Siyez). Ankara: Pegem Akademi Yayıncılık.

Stevens, J.P. (2002). Applied multivariate statistics for the social sciences. New York: Taylor \& Francis.

Tabachnick, B. G., \& Fidell, L. S. (2013). Using multivariate statistics. USA: Pearson Education Limited.

Tavşancıl, E. (2002). Tutumların ölçülmesi ve SPSS ile veri analizi. Ankara: Nobel Yayıncılık. 
Walter, J. L., \& Peller, J. E. (2000). Recreating brief therapy: Preferences and possibilities. New York, NY, US: W W Norton \& Co. 